\title{
Overview of bribery giving behaviors: Determinants and influence on firm performance
}

\author{
Vu Thi Hong Nhung ${ }^{1 *}$, Nguyen Thi Hong Huong ${ }^{1}$ \\ ${ }^{1}$ RMIT University, Vietnamese - German University, Vietnam \\ *Corresponding author: nhungvuct@gmail.com
}

\begin{abstract}
ARTICLE INFO
ABSTRACT

DOI: $10.46223 /$ HCMCOUJS.

econ.en.12.1.1953.2022

Received: June $21^{\text {st }}, 2021$

Revised: September $15^{\text {th }}, 2021$

Accepted: September $23^{\text {rd }}, 2021$

Keywords:

bribes; determinant; firm performance; paying bribery

Using findings on existing literature from 1986 to 2020, this paper provides an overview on understanding the theories, the determinants to explain bribery offering behavior, and the influence of paying bribes on firm performance. Based on our knowledge, we have found that there are three common theories including principal agent, residual control right and bargaining power theories that researchers have used to understand the motivation of paying bribes. Extant studies have shown supportive evidence that alongside business environment, both firm factors and business owner and manager characteristics have significant effects on a decision of paying bribes. Firms with high vulnerable exposure, such as young firms, firms with small and medium sizes, firms depending much on public services, or service firms, are more likely to pay bribes than others. Previous studies show both positive and negative effects of paying bribes on firm performance. However, vulnerable firms seem not to get many benefits when employing bribe payments.
\end{abstract}

\section{Introduction}

Bribery behavior has been attracted a lot of attention from scholars in various fields and studied both at a macro level and micro level (Luo, 2005) and cross-national level (Chen, Yaşar, $\&$ Rejesus, 2008). Although many countries have launched many national anti-corruption campaigns at a macro level, and many companies around the world have issued anti-bribery policies at a micro level, bribery continues to exist and is reflected through many scandalous cases of bribery. Bribery may lead to serious consequences such as declining political stability, economic growth, trust in government, weakening ethic, social standards, and increasing social inequality (Alesina \& Angeletos, 2005; Besley \& Persson, 2014; Mauro, 1995; Svensson, 2005; Zhao, Zhang, $\& \mathrm{Xu}, 2016)$. Bribery behavior involves both bribe givers or bribe offerers, which are the supply of bribes and bribe-takers which are the demand of bribes (Cuervo-Cazurra, 2006).

The main objective of this paper focuses only on providing an overview of the supply side of bribery behavior. This helps to understand the theories to explain for motivation of bribe givers, the characteristics of bribe givers and their firms, and the influence of bribery on their firm performance based on existing literature. Our review is based on published papers that we find on Google Scholar and Science Direct with the keywords "bribery", "bribe", "grease money", "bribery behaviors", "entrepreneur", "determinants", and "performance." The research period is 
limited to the period from 1986 to 2020 . After removing unqualified papers, our review is based on around 98 papers. This paper is contributed to existing overview studies in several aspects. First, we have updated both theories and empirical studies which have been discussed recently in bribery topic. Second, we have quite broad overview not only on factors that influence bribery giving behaviors but also how giving bribery affects firm performance. In our view, understanding both determinants of bribery-giving behaviors and the effect of giving bribery on firm performance can help us to have a clearer view on motivation and consequences of bribery-giving behaviors. This is expected to provide more relevant information for policymakers like managers, business owners, and the government when dealing with bribery issues. The paper is constructed as follows. In the second part, we will discuss the different concepts of bribery. Then we will continue to discuss different theories in giving bribery in the third section. We will reserve the fourth section to discuss determinants of giving bribery. Next, we will provide an overview of the influence of bribery on firm performance. Section 6 is conclusion.

\section{Concept of giving bribery}

Although giving bribery has various definitions, we can generalize these definitions in three aspects. First, giving bribery is an act of facilitating payment or "grease money", or offering, promising, or giving of something on purpose (Apke, 2001; Argandoña, 2005; He, 2000; Lindgreen, 2004). Second, bribe givers expect to influence a public official in the execution of his/her official duties in order obtain "advantages" such as legal, authorized services such as expediting an administrative process, obtaining a permit, license or service or gaining of tax exemption or reduction (Argandoña, 2005) or obtaining orders and other "improper advantage" to conduct international business including regulatory permits, customs, taxation and judicial and legislative proceedings (Apke, 2001). Thirdly, bribe giving is considered illegal and punishable by public policies, corporate codes of conduct, non-governmental organizations' codes of conduct, and international treaties (Sanyal \& Samanta, 2011; Tanzi, 1998).

\section{Theories of bribery giving}

Using different theories to help us to understand the motivation of bribe givers. First, employing the principal-agent theory, researchers argue that human beings are considered as selfinterested actors. Therefore, business owners or managers will try to maximize their benefits and minimize costs by making rational judgments (Klitgaard, 1988). Thus, in their view, offering bribe is a cost that is less than the obtained benefits for their businesses. Bribe giving may be a rational investment for their firms.

Second, based on the bargaining power theory, we learn that when both parties have equal weights in a negotiation, they will have equal bargaining power. The important factor that determines the equality or inequality of the bargaining is the threat point or fallback position of each party (Muthoo, 1999). In the context of SMEs, the threat points can be defined by the ability of firms to reallocate/ move their capital to other locations or abroad or close down their businesses and exit the industry (Lee, Oh, \& Eden, 2010). Thus, if entrepreneurs and firms have greater bargaining power in a negotiation process with public officials, they may not need to pay a bribe or pay less. The bargaining power represents the ability of entrepreneurs and firms to tolerate the pressure from public officials to pay bribery (Lee et al., 2010).

Thirdly, using the residual control theory of the firm, we notice that the agent owning the residual control on the main assets is the actual ownership of the firm (Grossman \& Hart, 1986; Hart \& Moore, 1990). The residual control right is defined as the right to control the firms' assets under situations not mentioned in "contractual terms." The allocation of property rights determines 
the residual control right of each holder. The higher the residual control right, the greater bargaining power in the decision-making process. We can argue that in the worst case, if the public officials take over the residual control rights, the owners/managers of the firms can use their fallback positions. Consequently, the bargaining power will depend not only on holding the residual control right but also on the ability to use threat points (Lee et al., 2010). Similar to the argument of bargaining power above, if firms "leave" the residual control rights to public officials, they may need to bribe public officials. If firms commit to transparent rules accept for risks of closing down their business, they may not agree to bribe public officials.

\section{Factors affect giving bribery behavior}

\subsection{Overview of bribery payment}

The percentage of firms that are mentioned that they pay bribes is varied in different studies. Pelizzo, Araral, Pak, and Xun (2016), using data from 10,457 firms in 30 countries in subSaharan Africa from 2009 to 2013 from the World Bank's Enterprise Survey, report that more than 25 percent of firms in the sample pay bribes. Similarly, Chen et al. (2008) also use data from 55 countries worldwide to show that $46 \%$ of firms in their sample pay bribes. Researches in Asian countries show quite a high percentage of paying bribes. For instance, using data from Special Survey on Governance (SSG) from Indonesia, Kuratko and Audretsch (2009) show that $74 \%$ of firms in 1,808 firms in their sample pay bribes. The annual bribes was around $10-15 \%$ of annual production costs. In a series of studies conducted in Vietnam, de Jong, Phan, and van Ees (2012) use the data from intensive interviews with entrepreneurs of 606 firms in six provinces of the Mekong River Delta, Vietnam, and report that $51 \%$ of firms pay bribes. In another study in Vietnam, de Jong and van Ees (2014) use data from the face-to-face interviews with 111 entrepreneurs of 111 firms in 13 provinces of the Mekong River Delta, Ho Chi Minh City and Binh Duong Province in 2009 and claim that $60 \%$ of entrepreneurs paid bribes. Although using a small sample of 176 firmsin Uganda in 1998, Svensson (2003) finds that 81 percent of firms reported that they paid bribes.

\subsection{Macro and firm characteristic factors}

Digging deeper into these studies, we classify factors that influence offering bribery behaviors in two groups. Groups of factors that related to macro and firm characteristics and groups of determinants that are related to business owner or manager characteristics.

The business environment is an important factor that may influence the firms' decision on paying bribes. In the environment of corrupted court systems, convoluted licensing requirements, nontransparent interpretation of laws and regulations, inefficient government service delivery, high taxes or new levies and new taxes, firms are more likely to pay bribes to public officials (Kuncoro, 2004; Pelizzo et al., 2016; X. Wu, 2009).

Using residual control right and bargaining power theories above, we may argue that in these nontransparent environment, firms cannot use their fallback positions. They need to pay bribes in order to maintain their survival. Pelizzo et al. (2016) confirm that the heavier these obstacles, the higher the likelihood of bribery offered by firms. X. Wu (2009) confirms that Asian firms will pay fewer bribes when the interpretation of laws and regulations is transparent, and government services are efficient.

Based on previous research, we find that not all firms in the same business environment pay bribes. Firms in different business sectors have a different incidence of paying bribes. Firms depending much on public services and public infrastructure are more likely to pay bribes or pay 
higher bribes than other firms (Chen et al., 2008; Svensson, 2003). It seems that these findings support residual control theories discussed above. Due to heavily relying on public services, public officials have greater residual control right in these firms, and firms need to bribe for their existence. Moreover, if firms face fierce market competition, they are more likely to bribe (Chen et al., 2008; X. Wu, 2009). Among different business sectors, previous studies show that trading firms and service firms have more involved in paying bribes or pay higher bribes than manufacturing ones (Chen et al., 2008; Kuncoro, 2004).

Regarding firm size, most researches confirm that small and medium-sized firms worldwide are more likely to bribe than larger ones (Chen et al., 2008; de Jong et al., 2012; Pelizzo et al., 2016; X. Wu, 2009). In addition, young firms are more likely to engage in bribery than wellestablished companies (de Jong et al., 2012; de Jong \& van Ees, 2014). Besides, Kuncoro (2004) also confirms that urban-based firms pay higher bribes than non-urban-based ones.

In general, although previous researches have used different data from different regions and countries, they have common findings that in nontransparent and high competitive business environment, more vulnerable firms, including young and small and medium firms, service or trading firms and firms relying on much on public services are more likely to pay bribes to support their survival. It seems these firms have a low probability of using fallback positions. That is why they choose to pay bribes to public officials otherwise; they may exit the business market. Among the different theories above, these findings support bargaining power and residual control right. Firms may decide to pay bribes because they have less bargaining power when discussing with public officials, and they do not have full residual control right of the assets in their firms. It is not clear from these previous findings that firms consider paying bribes as a potential investment.

\subsection{Managers' characteristic factors}

Besides firms' characteristics, factors related to entrepreneurs have considerably influenced paying bribe decisions. Especially in SMEs, due to no separation between ownership and control, business owners or managers involve directly in the most important business decisions. Tuliao and Chen (2017) using data of 5,837 companies from 21 countries from 2002 2005 covered by the Productivity and Investment Climate Survey (PICS) of the World Bank Group, find that male CEO is more likely to engage in bribery than female. Moreover, previous studies show that older, more work-experienced, and well-educated entrepreneurs (formal and informal education) are more likely to bribe than others (de Jong et al., 2012; de Jong \& van Ees, 2014; Phan, 2012). These studies also show that entrepreneurs who have personal relationships with local government officials are more likely to pay bribes, while those who have relationships with central government officials are less likely to bribe (de Jong \& van Ees, 2014). With these findings of characteristics of business owners or managers, the results seem to support the principal-agent theory discussed above. These entrepreneurs may consider paying bribery as a positive-sum game in their business, but it may not be a rational decision.

\section{Paying bribery and firm performance}

There are controversial effects of bribery on firm performance, but we can group it into two main groups. First, many empirical studies show that bribery a "grease the wheels" instrument that helps speed up the bureaucratic procedures; improve the efficiency of public services, especially in countries with poor policies and legal systems. Second, extant researches describe bribery as "dust in the wheels" which hurt firms' growth, innovation capability, and productivity (Mauro, 1995). 


\subsection{Positive effects of paying bribery}

There are various measurements of firm performance. First, it is common for previous studies investigate the influence of paying bribes on sales. Williams, Martinez-Perez, and Kedir (2016), using a cross-national dataset from World Bank Enterprise Survey in 132 developing countries, show that $25.3 \%$ of enterprises stated that payment of bribes to public officials is necessary to get a thing done. Enterprises viewing payment of bribes to a public official as necessary to get things done have significantly higher annual sales than those not viewing payment of bribes to a public official as necessary. In another study, using a different dataset from SMEs in Philippines, Mendoza, Lim, and Lopez (2015) also report a positive effect of bribery on sales, for instance, a one percent point increase in informal payment leads to sales growth increase by 1.16 percent point.

Besides the effect on sales, other studies show the positive influence of bribery on productivity, innovation or production output growth, or employment growth. For instance, Kasuga (2013), employing data from garment- producing firms in Cambodia, reports that bribery can improve productivity by reducing bureaucratic delay. One percent increase in bribe payments saves 1.7 days and generates about a 1.3 percent increase in output per employee. Similarly, Williams et al. (2016) also report that productivity growth rates in firms that appreciate bribery payment are higher than other firms. Supporting for a positive effect of bribery payment, R. Wu and Meeks (2020), using data from transition economies in Central Asia and Eastern Europe, find that paying bribery could increase a firm's production output and employment growth significantly, and bribing firms are more likely to bribe again three years later. The previous study also shows the positive effect of paying bribes on innovation engagement. Using data of SMEs in Vietnam, Nguyen, Doan, Nguyen, and Tran (2016) show that small informal fees help firms to speed up the bureaucracy, and they lead to improvement in overall innovation and product innovation.

\subsection{Negative effects of paying bribery}

Contradicted to the positive effects above, many studies show that paying bribes impedes firm performance. Using enterprise surveys' firm-level data for 29 countries from the Latin America and Caribbean (LAC) region conducted by the World Bank, Şeker and Yang (2014) show that bribing firms have $23.6 \%$ lower annual sales growth than non-bribing firms. Bribing firms had an average growth rate of $0.8 \%$ compared to $3.4 \%$ among non-bribing firms. Moreover, bribery hurts firms with low sales and young firms more than other firms. Similarly, O'Toole and Tarp (2014) using data from firm-level data from the World Bank Enterprise Surveys of 90 developing and transition countries, shows that one percent increase in informal payment leads to sales-to-capital ratio decrease by 3.28 percent and profit-to-capital ratio decrease by 2.98 percent point. In another study, Zhou and Peng (2012) also use the World Business Environment Survey (WBES) data conducted by the World Bank, including 2,686 firms in 48 countries. They find that bribery hurts firms' sales growth and is costly to firms' operation. Bribery retards SMEs' performance than large ones. Similarly, Athanasouli, Goujard, and Sklias (2012) also find bribery payment increase leads to decrease in firm growth in Greece and this effect is stronger for SMEs firms than other ones. In addition, using BEEPS - Amadeus dataset, other studies also find similar negative effects of bribery on sales and labor productivity growth (Hanousek \& Kochanova, 2016; Kochanova, 2012).

Besides the negative effect on sales and productivity, bribery also hinders efficiency innovation engagement of firms. For instances, McArthur and Teal (2002), using data from 27 African countries, show that firms in corrupted countries are 70 percent less efficient than firms in the least corrupt countries. Firms operating in the high-bribery countries are, on average two-thirds 
less productive than their counterparts operating in bribe-free countries. In another study, $\mathrm{R}$. Wu (2019) also shows that bribery was found to have a significantly negative impact on both innovation capability and productivity of the observed firms. These negative effects of bribery on innovation capability and productivity are also confirmed in another paper conducted by $\mathrm{R}$. Wu and Meeks (2020) in transition economies in Central Asia and Eastern Europe.

\section{Conclusion}

Based on the existing literature, this paper provides an overview on understanding the theories, the determinants to explain bribery offering behavior, and the influence of paying bribes on firm performance. In general, we find there are three common theories, including principalagent, residual control right, and bargaining power theories, that researchers have used to understand the motivation of paying bribes. It seems the findings on existing literature support these three theories.

Among different factors that help to understand the motivation of paying bribes, the business environment plays a considerable role in decision paying bribes of firms. In general, poorer financial market development, low transparency legal system, higher policy uncertainty may lead to a significantly higher incidence of bribery payment by firms. Interestingly, more vulnerable firms such as young firms, firms with small and medium sizes, firms depending more on public services, or services are more willing to pay bribes. It seems residual control right and bargaining power are dominant in support these findings. Vulnerable firms have less bargaining power and residual control right; they use bribes as a tool to maintain their existence and survival.

Although there is some evidence showing that firms may benefit from improvement in sales, productivity or innovation due to increase bargaining power with public officials, bribe payment may lead to increased expenditure in firms, which leads to a decrease in sales, productivity, or innovation. It should be noted that using bribe payment is less effective for SMEs to improve their firm performance. Due to the high vulnerability level, SMEs seem to lose more than gain when employing bribe strategy.

\section{References}

Alesina, A., \& Angeletos, G.-M. (2005). Corruption, inequality, and fairness. Journal of Monetary Economics, 52(7), 1227-1244.

Apke, T. M. (2001). Impact of OECD Convention anti- bribery provisions on international companies. Managerial Auditing Journal, 16(2), 58-62.

Argandoña, A. (2005). Corruption and companies: The use of facilitating payments. Journal of Business Ethics, 60(3), 251-264.

Athanasouli, D., Goujard, A., \& Sklias, P. (2012). Corruption and firm performance: Evidence from Greek firms. International Journal of Economic Sciences and Applied Research, 5(2), 43-67.

Besley, T., \& Persson, T. (2014). Why do developing countries tax so little? Journal of Economic Perspectives, 28(4), 99-120.

Chen, Y., Yaşar, M., \& Rejesus, R. M. (2008). Factors influencing the incidence of bribery payouts by firms: A cross-country analysis. Journal of Business Ethics, 77(2), 231-244.

Cuervo-Cazurra, A. (2006). Who cares about corruption? Journal of International Business Studies, 37(6), 807-822. 
de Jong, G., \& van Ees, H. (2014). Firms and corruption. European Management Review, 11(3/4), 187-190.

de Jong, G., Phan, T. A., \& van Ees, H. (2012). Which entrepreneurs bribe and what do they get from it? Exploratory evidence from Vietnam. Entrepreneurship Theory and Practice, 36(2), 323-345.

Grossman, S., \& Hart, O. (1986). The costs and benefits of owner'ship: A theory of lateral and vertical integration. Journal of political economy, 94(4), 691-719.

Hanousek, J., \& Kochanova, A. (2016). Bribery environments and firm performance: Evidence from CEE countries. European Journal of Political Economy, 43(1), 14-28.

Hart, O., \& Moore, J. (1990). Property rights and the nature of the firm. Journal of Political Economy, 98(6), 1119-1158.

He, Z. (2000). Corruption and anti-corruption in reform China. Communist and Post-Communist Studies, 33(2), 243-270.

Kasuga, H. (2013). Why do firms pay bribes? Firm- level evidence from the Cambodian garment industry. Journal of International Development, 25(2), 276-292.

Klitgaard, R. (1988). Controlling corruption. Oakland, CA: University of California Press.

Kochanova, A. (2012). The impact of bribery on firm performance: Evidence from central and eastern European countries (CERGE-EI Working Paper Series (473)). Retrieved May 10, 2021, from https://ssrn.com/abstract=2191094

Kuncoro, A. (2004). Bribery in Indonesia: Some evidence from micro-level data. Bulletin of Indonesian Economic Studies, 40(3), 329-354.

Kuratko, D. F., \& Audretsch, D. B. (2009). Strategic entrepreneurship: Exploring different perspectives of an emerging concept. Entrepreneurship Theory and Practice, 33(1), 1-17.

Lee, S.-H., Oh, K., \& Eden, L. (2010). "Why do firms bribe?” Management International Review, 50(6), 775-796.

Lindgreen, A. (2004). Corruption and unethical behavior: Report on a set of Danish guidelines. Journal of Business Ethics, 51(1), 31-39.

Luo, Y. (2005). An organizational perspective of corruption. Management and Organization Review, 1(1), 119-154.

Mauro, P. (1995). Corruption and growth. The Quarterly Journal of Economics, 110(3), 681-712.

McArthur, J., \& Teal, F. (2002). Corruption and firm performance in Africa. Oxford, UK: University of Oxford.

Mendoza, R. U., Lim, R. A., \& Lopez, A. O. (2015). Grease or sand in the wheels of commerce? Firm level evidence on corruption and SMEs. Journal of International Development, 27(4), 415-439.

Muthoo, A. (1999). Bargaining theory with applications. Cambridge, UK: Cambridge University Press.

Nguyen, A. N., Doan, H. Q., Nguyen, M. N., \& Tran, B. N. (2016). The impact of petty corruption on firm innovation in Vietnam. Crime, Law and Social Change, 65(4), 377-394. 
O'Toole, C. M., \& Tarp, F. (2014). Corruption and the efficiency of capital investment in developing countries. Journal of International Development, 26(5), 567-597.

Pelizzo, R., Araral, E., Pak, A., \& Xun, W. (2016). Determinants of bribery: Theory and evidence from Sub- Saharan Africa. African Development Review, 28(2), 229-240.

Phan, T. A. (2012). The impact of entrepreneurial characteristics on bribery incidence in transition economies. Asian Academy of Management Journal, 17(2), 155-175.

Sanyal, R., \& Samanta, S. (2011). Trends in international bribe-giving: Do anti-bribery laws matter? Journal of International Trade Law and Policy, 10(2), 151-164.

Şeker, M., \& Yang, J. S. (2014). Bribery solicitations and firm performance in the Latin America and Caribbean region. Journal of Comparative Economics, 42(1), 246-264.

Svensson, J. (2003). Who must pay bribes and how much? Evidence from a cross section of firms. The Quarterly Journal of Economics, 118(1), 207-230.

Svensson, J. (2005). Eight questions about corruption. Journal of Economic Perspectives, 19(3), $19-42$.

Tanzi, V. (1998). Corruption around the world: Causes, consequences, scope, and cures. Staff Papers, 45(4), 559-594.

Tuliao, K. V., \& Chen, C.-w. (2017). CEO duality and bribery: The roles of gender and national culture. Management Decision, 55(1), 218-231.

Williams, C. C., Martinez-Perez, A., \& Kedir, A. (2016). Does bribery have a negative impact on firm performance? A firm-level analysis across 132 developing countries. International Journal of Entrepreneurial Behavior \& Research, 22(3), 398-415.

Wu, R. (2019). Firm development and bribery: An empirical study from Latin America. Atlantic Economic Journal, 47(1), 53-64.

Wu, R., \& Meeks, A. (2020). How does bribery affect a firm's future growth? Empirical evidence from transition economies. Post-Communist Economies, 32(3), 409-427.

$\mathrm{Wu}, \mathrm{X}$. (2009). Determinants of bribery in Asian firms: Evidence from the world business environment survey. Journal of Business Ethics, 87(1), 75-88.

Zhao, H., Zhang, H., \& Xu, Y. (2016). Does the dark triad of personality predict corrupt intention? The mediating role of belief in good luck. Frontiers in Psychology, 7(1), 608-608.

Zhou, J. Q., \& Peng, M. W. (2012). Does bribery help or hurt firm growth around the world? Asia Pacific Journal of Management, 29(4), 907-921.

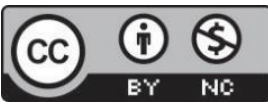

Creative Commons Attribution-NonCommercial 4.0 International License. 